\title{
Multi-year methane ebullition measurements from water and bare peat surfaces of a patterned boreal bog
}

\author{
Elisa Männistö ${ }^{1}$, Aino Korrensalo ${ }^{1}$, Pavel Alekseychik ${ }^{2}$, Ivan Mammarella ${ }^{2}$, Olli Peltola ${ }^{2}$, Timo Vesala ${ }^{2,3}$, and \\ Eeva-Stiina Tuittila ${ }^{1}$ \\ ${ }^{1}$ Peatland and Soil Ecology Research Group, School of Forest Sciences, University of Eastern Finland, \\ P.O. Box 111, 80101 Joensuu, Finland \\ ${ }^{2}$ Institute for Atmospheric and Earth System Research/Physics, Faculty of Science, University of Helsinki, \\ P.O. Box 68, 00014 Helsinki, Finland \\ ${ }^{3}$ Institute for Atmospheric and Earth System Research/Forest Sciences, Faculty of Agriculture and Forestry, \\ University of Helsinki, P.O. Box 27, 00014 Helsinki, Finland
}

Correspondence: Elisa Männistö (elisa.mannisto@uef.fi)

Received: 31 December 2018 - Discussion started: 14 January 2019

Revised: 10 May 2019 - Accepted: 28 May 2019 - Published: 14 June 2019

\begin{abstract}
We measured methane ebullition from a patterned boreal bog situated in the Siikaneva wetland complex in southern Finland. Measurements were conducted on water (W) and bare peat surfaces (BP) in three growing seasons (2014-2016) using floating gas traps. The volume of the trapped gas was measured weekly, and methane and carbon dioxide $\left(\mathrm{CO}_{2}\right)$ concentrations of bubbles were analysed from fresh bubble samples that were collected separately. We applied a mixed-effect model to quantify the effect of the environmental controlling factors on the ebullition.

Ebullition was higher from $\mathrm{W}$ than from BP, and more bubbles were released from open water (OW) than from the water's edge (EW). On average, ebullition rate was the highest in the wettest year (2016) and ranged between 0 and $253 \mathrm{mg} \mathrm{m}^{-2} \mathrm{~d}^{-1}$ with a median of $2 \mathrm{mg} \mathrm{m}^{-2} \mathrm{~d}^{-1}, 0$ and $147 \mathrm{mg} \mathrm{m}^{-2} \mathrm{~d}^{-1}$ with a median of $3 \mathrm{mg} \mathrm{m}^{-2} \mathrm{~d}^{-1}$, and 0 and $186 \mathrm{mg} \mathrm{m}^{-2} \mathrm{~d}^{-1}$ with a median of $28 \mathrm{mg} \mathrm{m}^{-2} \mathrm{~d}^{-1}$ in 2014 , 2015, and 2016, respectively. Ebullition increased together with increasing peat temperature, weekly air temperature sum and atmospheric pressure, and decreasing water table (WT). Methane concentration in the bubbles released from W was 15-20 times higher than the $\mathrm{CO}_{2}$ concentration, and from BP it was 10 times higher. The proportion of ebullition fluxes upscaled to ecosystem level for the peak season was $2 \%-8 \%$ and $2 \%-5 \%$ of the total flux measured with eddy covariance technique and with chambers and gas traps, respectively. Thus, the contribution of methane ebullition from
\end{abstract}

wet non-vegetated surfaces of the bog to the total ecosystemscale methane emission appeared to be small.

\section{Introduction}

Historically, bogs were commonly feared, as people saw mysterious lights that gave rise to the tales of the "will o' the wisps" that lure travellers from their paths to sink into bog holes (Meredith, 2002). Nowadays, these lights are thought to be the spontaneous combustion of peatland gases, such as methane, bubbling into the atmosphere, rather than deceptive fairies. However, the widespread folklore indicates that the phenomenon is well known around the world in peatland-rich areas. Although currently peatlands are more known for their climate-cooling impact as small carbon sinks and the storage of a third of the global soil carbon stock (Strack, 2008), they are also a major natural source of methane, a potent climate warming greenhouse gas (IPCC, 2014). The same high water table (WT) conditions that support accumulation of organic material as peat by slowing down aerobic decomposition also favour methane production by anaerobic microbes, methanogens (Archaea) (Hanson and Hanson, 1996). It has been predicted that carbon dioxide $\left(\mathrm{CO}_{2}\right)$ uptake typically offsets sustained methane emissions in natural ecosystems in the long term (i.e. several centuries), albeit with large spatiotemporal variability (Petrescu et al., 2015). 
Methane is emitted from peatlands into the atmosphere via three routes: by diffusion from peat, transport through aerenchymatous vascular plants and by episodic bubble release, i.e. ebullition (LeMer and Roger, 2001; Raghoebarsing et al., 2005). A large part of the produced methane is oxidised by methanotrophic bacteria in the aerobic peat layer above water level (Hanson and Hanson, 1996; LeMer and Roger, 2001; Larmola et al., 2010), and thus methane flux rate of a peatland depends on the rates of methane production and consumption, in addition to transportation within the peat to the atmosphere. It is known that part of methane can also be oxidised in plants, such as rice (Bosse and Frenzel, 1997), but so far significant methane oxidation has not been detected in bog plants, such as Eriophorum spp. (Frenzel and Rudolph, 1998). As methane emitted through vascular plants or by ebullition bypasses the oxidation in the aerobic peat layer, these pathways can potentially release high amounts of methane into the atmosphere. Diffusion through peat and vascular plants have been regarded as being the dominant pathways of methane emissions and those emission pathways have been largely targeted with chamber measurements (e.g. Bubier et al., 2005; Ström et al., 2005; Turetsky et al., 2014). Alternatively, the eddy covariance (EC) technique is used to estimate the integrated ecosystem-scale methane flux (e.g. Brown et al., 2014; Rinne et al., 2018) but is unable to differentiate the emission pathways.

Current models of the global methane budget are still uncertain due to limited knowledge of the relative contribution of different factors controlling methane fluxes (Riley et al., 2011). The largest source of uncertainty is the quantity of methane emissions from natural wetlands, such as peatlands (Riley et al., 2011; Melton et al., 2013). Within peatland emissions, the largest uncertainty is related to the magnitude of ebullition (Peltola et al., 2018). We are aware of only few studies that have directly measured ebullition from boreal peatlands with gas traps. In the first one, Hamilton et al. (1994) carried out measurements over $24 \mathrm{~h}$ and found no bubbles. In three other studies conducted in a fen (Strack et al., 2005; Strack and Waddington, 2008) or a bog (Stamp et al., 2013) ebullition fluxes between 7 and $96 \mathrm{mg} \mathrm{CH}_{4} \mathrm{~m}^{-2} \mathrm{~d}^{-1}$ were detected, but the importance of ebullition for the ecosystem flux remained unrevealed. Ebullition has also been measured in the field by separating peak methane releases from steady chamber flux (Riutta et al., 2007; Tokida et al., 2007; Goodrich et al., 2011) with emissions varying from $49-152 \mathrm{mg} \mathrm{CH}_{4} \mathrm{~m}^{-2} \mathrm{~d}^{-1}$ (Goodrich et al., 2011) to $48-1440 \mathrm{mg} \mathrm{CH}_{4} \mathrm{~m}^{-2} \mathrm{~d}^{-1}$ (Tokida et al., 2007). These studies show contrasting results in relation to the contribution of ebullition to the total emission. While Riutta et al. (2007) estimated the role of ebullition to be small in the two study years, Tokida et al. (2007) (with two sample plots) found that the proportion of ebullition may constitute up to $50 \%$ of the total flux. Results on mesocosm studies in laboratory conditions are similarly disparate as they show that the proportion of ebullition in the total emission varies from $3 \%$ (Green and Baird, 2013) to 50\% (Christensen et al., 2003).

Similar to chamber and EC measurements (Rinne et al., 2007, 2018; Jackowicz-Krczyński et al., 2010; Turetsky et al., 2014; Mikhaylov et al., 2015), direct ebullition studies have connected the rate of methane emission to peat temperature (Strack et al., 2005) related to increasing microbial activity (Conrad et al., 1997). It is noteworthy that the incoming energy flux has been shown to primarily control the methane production and ebullition in shallow subarctic lakes (Wik et al., 2014) that could be contrasted to peatland pools. Ebullition in peatlands has additionally been linked to decreasing WT and falling atmospheric pressure: the decrease in hydrostatic pressure increases the volume of the gas phase of methane in peat and releases it into the atmosphere (Tokida et al., 2007). Also, an increase in atmospheric pressure can trigger ebullition by decreasing the bubble size, due to compression, and thus increasing the bubble mobility in shallow peat (Comas et al., 2011; Chen and Slater, 2015). Furthermore, peat structure has been shown to affect bubble sizes and determine whether ebullition is steady or erratic (Ramirez et al., 2016). However, the importance of these factors for ebullition is still based on only a few studies, of which the longest covers two growing seasons (Strack and Waddington, 2008).

In this study, we measured methane ebullition from open water pools (W) and bare peat surfaces (BP) with gas traps in three consecutive growing seasons (2014-2016) in a boreal bog where methane fluxes were also measured with EC and static chamber techniques. We aimed to (1) quantify the spatial and temporal variation in methane ebullition from wet bog surfaces, (2) study the controlling factors and (3) assess the contribution of ebullition from wet surfaces to the ecosystem-level emission.

\section{Materials and methods}

The study was conducted in the ombrotrophic bog that is part of Siikaneva peatland complex situated in southern Finland $\left(61^{\circ} 50^{\prime} \mathrm{N}, 24^{\circ} 12^{\prime} \mathrm{E}, 160 \mathrm{~m}\right.$ a.s.l.), within the southern boreal vegetation zone (Ahti et al., 1968). Annual rainfall in the area is $707 \mathrm{~mm}$, the snow depth in March (with the thickest snow cover) is $36 \mathrm{~cm}$, the annual cumulative temperature is 1318 , the length of growing season is $168 \mathrm{~d}$, the average annual temperature is $4.2^{\circ} \mathrm{C}$, and the average temperatures in January and July are -7.2 and $17.1^{\circ} \mathrm{C}$, respectively (30year averages from the nearby Juupajoki-Hyytiälä weather station, except snow depth, which uses a 20 -year average). The microtopography of the studied bog site varies from $\mathrm{W}$ and BP to hollows, lawns and hummocks. W and BP together cover approximately one-fourth of the site (W $11.6 \%$ and BP $15.3 \%$ within a $30 \mathrm{~m}$ radius from the EC tower of the site). The bottom layer is formed by Sphagnum mosses, except in $\mathrm{W}$ and BP that are devoid of moss. Sedges are the dominant vascular plants in hollows and lawns, whereas vascular plant 
vegetation on hummocks is dominated by dwarf shrubs. In BP, Rhynchospora alba is often the only plant species (Korrensalo et al., 2018a).

In order to measure methane ebullition from the studied bog, floating gas traps were placed in W and BP in three consecutive years (2014-2016). Only W and BP microforms were chosen because we expected high ebullition from these waterlogged surfaces that have almost no vegetation, and the sampling method required gas traps to be easily filled with water. BP are patches of visible peat that have WT at or near the surface. For example, in 2014, WT in BP was on average $-1.8 \mathrm{~cm}$. W are without a clear bottom but have on average $1 \mathrm{~m}$ of water over very loose peat slurry and their water area starts directly from the edge of the surrounding moss cover. As it is difficult to determine what is the bottom of the pools, we did not measure the water depth or temperature in the bottom of the $\mathrm{W}$.

The gas traps were constructed from inverted plastic funnels with diameters ranging between 14.3 and $24.5 \mathrm{~cm}$ (Fig. 1). A syringe with a three-way stopcock was attached to the narrow end of each funnel, and the joint was covered with sealant to make it airtight. A piece of metallic netting coated with filter fabric was glued inside the funnels to prevent litter and small animals from entering the gas traps in the open water pools. The gas traps on $\mathrm{W}$ were attached to a floating styrofoam raft and placed in the pools in lines of two or three gas traps, anchored to the opposing shores of the pool with string (Fig. 1). To study the potential difference in availability of substrate for methanogenesis, some gas traps were anchored further away from the surrounding moss cover at the centre of the pools (open water, OW), while the other gas traps were anchored at the water's edge (EW) right next to the moss (Fig. 2). The gas traps on BP were placed next to boardwalks at the study site (Fig. 2). The air was sucked out of the gas traps with an extra syringe until they were filled with water. The rate of ebullition was measured weekly by sampling the gas volume that had replaced water in each gas trap.

A total of 16 gas traps were used (11 in W and 5 in BP) from 3 June to 25 September in 2014, 20 gas traps (13 in $\mathrm{W}$ and 7 in BP) were used from 13 May to 24 September in 2015 and 18 gas traps (12 in W and 6 in BP) were used from 27 May to 9 September in 2016.

Methane concentrations of the gas caught in the gas traps during the weekly sampling periods were measured in 2014 and compared with methane concentration of fresh ebullition samples. We found methane concentrations in the gas traps to be clearly lower than in the fresh ebullition samples (Table A1 in the Appendix), and thus methane concentration of the gas caught in the traps was assumed to dilute during the weekly sampling periods due to diffusion. Therefore, methane concentration of the releasing bubbles was not measured from the weekly samples but instead by collecting fresh ebullition samples from $\mathrm{W}$ without disturbing the gas traps and from BP that had no gas traps. Ebullition was trig-

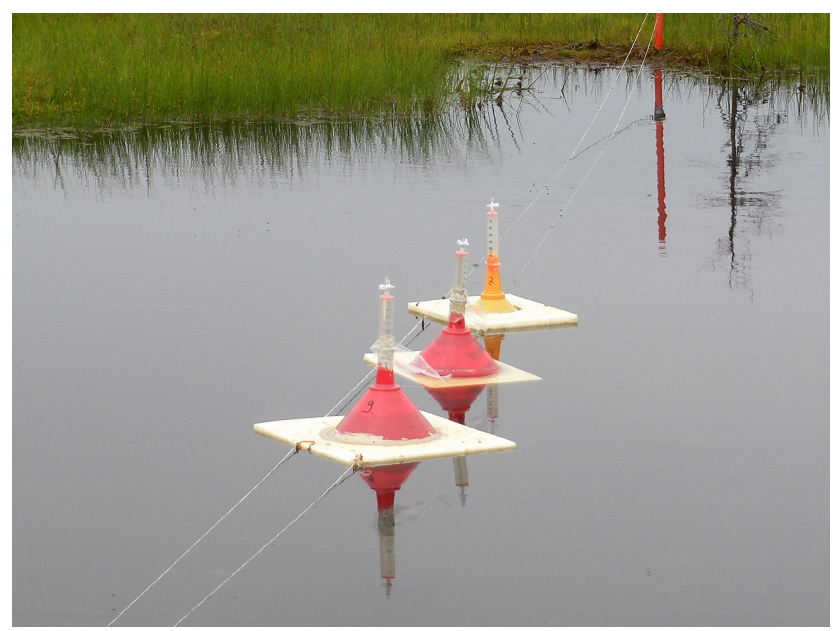

Figure 1. Floating gas traps in an open water peatland pool (OW).

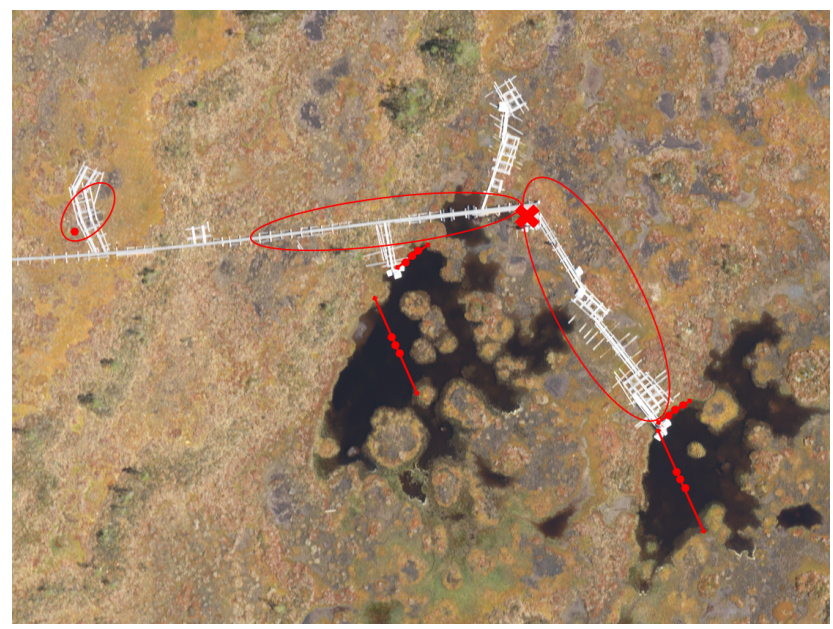

Figure 2. Aerial photo of the study site in Siikaneva bog. Red lines with dots mark the floating gas traps in open water (OW) and at the water's edge (EW). Red circles mark the area where the gas traps were placed on bare peat surfaces (BP), which are seen as brownishgrey in the photo. The eddy covariance (EC) raft is marked with the red $x$.

gered manually from the sampled surfaces and the formed bubbles were caught in an extra gas trap, from where $20 \mathrm{~mL}$ samples were taken into vacuumed glass vials. The samples were analysed with an Agilent Technologies HP 8690 gas chromatograph at the Natural Resources Institute Finland (LUKE), Vantaa. Fresh ebullition samples were collected 4 times during the measurement season in 2014 and 2016 and 13 times in 2015. Average methane concentration was interpolated linearly from the fresh ebullition samples for each weekly measurement day.

Average methane emission by ebullition as $\mathrm{mL} \mathrm{m}^{-2} \mathrm{~d}^{-1}$ was calculated based on the area of the gas trap, number of days and volume of gas collected in each measurement period and the average methane concentration of each 
measurement period. In order to convert the emissions to $\mathrm{mg} \mathrm{m}^{-2} \mathrm{~d}^{-1}$, methane density in each measurement period was calculated based on the average air temperature of the measurement period in degrees Celsius and the standard atmospheric air pressure, $101325 \mathrm{~Pa}$. Average methane emission $\left(\mathrm{mg} \mathrm{m}^{-2} \mathrm{~d}^{-1}\right)$ was calculated separately for ebullition from OW, EW and BP.

In order to compare the ebullition fluxes to EC and chamber measurements (Korrensalo et al., 2018b), the ebullition flux was upscaled to ecosystem level by linearly interpolating the total average ebullition that was calculated as a sum of average ebullition fluxes from $\mathrm{W}$ and $\mathrm{BP}$ weighted with their relative surface areas.

Air pressure and temperature data from 2014 to 2016 were received from the Juupajoki-Hyytiälä weather station that is situated about $6 \mathrm{~km}$ from the study site in Siikaneva. The data on WT, water temperature and peat temperatures at the depths of 5, 20 and $50 \mathrm{~cm}$ were received from data loggers installed in a lawn about $1.5 \mathrm{~m}$ away from the EC raft. Photosynthetically active radiation (PAR) data was measured at the site.

Linear mixed-effect models were used to analyse the effect of measured environmental variables (peat temperature in different depths, WT, atmospheric pressure and cumulative PAR, and effective temperature sum of a measurement period as variables of incoming energy flux) on log-transformed ebullition flux rates. The gas trap was included as a random effect in the model. We also tested which of the four peat temperature variables explained the variation in ebullition fluxes the best. The data were analysed with the function lme of the package nlme of the R software (version 3.3.2).

\section{Results}

Among the three studied years, the year 2014 was the warmest, driest and had the highest amount of cumulative photosynthetically active radiation (PAR) (Finnish Meteorological Institute open data) (Table 1). It was also warmer than the 30-year average. The year 2015 was the coolest, with a lowered annual rainfall and PAR, while 2016 was the wettest and the cloudiest year (Table 1). All 3 years were significantly drier than the average (Table 1).

Measured methane ebullition ranges were $0-253,0$ 147 and $0-186 \mathrm{mg} \mathrm{m}^{-2} \mathrm{~d}^{-1}$ with medians 2,3 and $28 \mathrm{mg} \mathrm{m}^{-2} \mathrm{~d}^{-1}$ in 2014, 2015 and 2016, respectively (Fig. A1 in the Appendix). Weekly medians of individual gas traps were $0-57 \mathrm{mg} \mathrm{m}^{-2} \mathrm{~d}^{-1}$ in $2014,0-33 \mathrm{mg} \mathrm{m}^{-2} \mathrm{~d}^{-1}$ in 2015 and $10-67 \mathrm{mg} \mathrm{m}^{-2} \mathrm{~d}^{-1}$ in 2016. The 3 years differed (degrees of freedom, $\mathrm{DF}=2,746 ; p<0.0001$ ) as slightly higher ebullition fluxes were generally obtained in 2015 than 2014, while, on average, the ebullition fluxes were at their highest in the wettest year (2016).
Table 1. Effective temperature sum of the growing season, annual rainfall and the cumulative photosynthetically active radiation (PAR) in the three studied years (2014-2016), compared to the 30year averages of the area. Data for the Hyytiälä weather station are from Finnish Meteorological Institute open data.

\begin{tabular}{lrrr}
\hline Year & $\begin{array}{r}\text { Temp. sum } \\
{ }^{\circ} \mathrm{C}\end{array}$ & $\begin{array}{r}\text { Annual rainfall } \\
\mathrm{mm}\end{array}$ & $\begin{array}{r}\text { PAR } \\
\mu \mathrm{mol} \mathrm{m}{ }^{-2}\end{array}$ \\
\hline 2014 & 1349 & 579 & 70800 \\
2015 & 1166 & 658 & 69180 \\
2016 & 1280 & 660 & 67996 \\
30 -year mean & 1318 & 707 & - \\
\hline
\end{tabular}

Higher ebullition was observed on W than on BP (Fig. 3) $(\mathrm{DF}=1,746 ; p<0.0001)$. Ebullition from $\mathrm{OW}$ was significantly higher than ebullition from EW, except in the middle of the growing season 2015 (Fig. 3). Although BP showed lower ebullition with fewer peaks than $\mathrm{W}$, all the surfaces had the same seasonal ebullition pattern each year, with highest fluxes observed in August (Fig. 3). However, in 2015 the highest ebullition was measured later than in other years after relatively low ebullition in late summer (Fig. 3).

Ebullition increased with increasing average peat temperature at the depth of $5 \mathrm{~cm}(\mathrm{DF}=1,746 ; p<0.0001)$ that explained ebullition better than the other peat temperature variables measured. The seasonal pattern of ebullition followed the temperature in each year (Fig. 4). Higher ebullition rates were also explained with decreasing average $\mathrm{WT}(\mathrm{DF}=1$, $746 ; p=0.0001)$. The highest ebullition peaks were associated with the lowest WT in each year (Fig. 4). A prolonged depression of WT further explained the late peak of ebullition in 2015, as well as the increase in ebullition in the autumn 2016 (Fig. 4). Change in atmospheric pressure during the measurement period further explained ebullition: more bubbles were released with a higher increase in pressure $(\mathrm{DF}=1$, 746; $p=0.001$ ). Some events of ebullition might be directly related to decreasing atmospheric pressure, such as the small peak in ebullition in mid-August 2014 that appears to be better explained by the long decrease in atmospheric pressure than by peat temperature or WT (Fig. 5). After including peat temperature, WT and change in atmospheric pressure, the effective temperature sum of a measurement period still had a positive effect on ebullition ( $\mathrm{DF}=1,746 ; p=0.0351$. Finally, the cumulative PAR had no significant effect on ebullition and was excluded from the final model.

Fresh ebullition sample analyses showed that the released gas bubbles contained more methane than $\mathrm{CO}_{2}$. Methane concentration of bubbles released from W was 15-20 times higher than their $\mathrm{CO}_{2}$ concentration, while bubbles from $\mathrm{BP}$ had a methane concentration tenfold higher than their $\mathrm{CO}_{2}$ concentration (Table 2).

The average ebullition flux upscaled to ecosystem level was an order of a magnitude lower than the net methane flux 
Table 2. Average methane $\left(\mathrm{CH}_{4}\right)$ and carbon dioxide $\left(\mathrm{CO}_{2}\right)$ concentrations $\left(\mathrm{mLL}^{-1}\right)$, with the standard deviation $(\mathrm{SD})$ of gas-releasing bubbles from pools (W) and bare peat surfaces (BP) in the three studied years (2014-2016).

\begin{tabular}{lrr|rr|rr}
\hline & \multicolumn{2}{c|}{2014} & \multicolumn{2}{|c|}{2015} & \multicolumn{2}{c}{2016} \\
\cline { 2 - 6 } & Average & SD & Average & SD & Average & SD \\
\hline $\mathrm{W} \mathrm{CH}_{4}$ & 380.0 & 50.7 & 285.0 & 93.0 & 423.0 & 103.9 \\
$\mathrm{~W} \mathrm{CO}_{2}$ & 23.8 & 4.9 & 18.0 & 8.8 & 20.8 & 6.5 \\
$\mathrm{BP} \mathrm{CH}_{4}$ & 274.2 & 64.5 & 273.6 & 56.1 & 364.2 & 123.7 \\
$\mathrm{BP} \mathrm{CO}_{2}$ & 29.4 & 16.0 & 26.9 & 9.4 & 31.8 & 8.9 \\
\hline
\end{tabular}

Table 3. Monthly cumulative methane fluxes $\left(\mathrm{mg} \mathrm{m}^{-2}\right.$ month $\left.^{-1}\right)$, measured as ebullition and with the eddy covariance (EC) technique for June-August in the three studied years (2014-2016).

\begin{tabular}{lrrr|rrr|rrr}
\hline & \multicolumn{3}{c}{2014} & & 2015 & & 2016 \\
\cline { 2 - 9 } & Ebullition & EC & $\begin{array}{r}\text { \% of } \\
\text { ebullition }\end{array}$ & Ebullition & EC & $\begin{array}{r}\text { \% of } \\
\text { ebullition }\end{array}$ & Ebullition & EC & $\begin{array}{r}\% \text { of } \\
\text { ebullition }\end{array}$ \\
\hline June & 27 & 1668 & 2 & 73 & 1139 & 6 & 117 & 2530 & 5 \\
July & 155 & 3423 & 5 & 112 & 2277 & 5 & 314 & 4216 & 7 \\
August & 176 & 3447 & 5 & 223 & 2657 & 8 & 249 & 3448 & 7 \\
\hline
\end{tabular}

measured by EC in each year (Fig. 6). The sum of ebullition and upscaled chamber flux in 2014 was higher than the one measured with EC, but the two estimates followed the same seasonal trend (Fig. 6). The contribution of ebullition to the total methane flux measured with chambers and bubble traps during the peak season in 2014 was $2 \%, 3 \%$ and $5 \%$ in June, July and August, respectively (Table 3). The contribution of ebullition to EC flux during the peak season varied from $2 \%$ in June 2014 to $8 \%$ in August 2015 (Table 3).

\section{Discussion}

\subsection{The magnitude of ebullition}

The methane ebullition measured in this study ranged from 0 to $253 \mathrm{mg} \mathrm{m}^{-2} \mathrm{~d}^{-1}$ and the seasonal weekly median of ebullition for different surfaces ranged from 0 (measured from $\mathrm{BP}$ in 2014) to $37 \mathrm{mg} \mathrm{m}^{-2} \mathrm{~d}^{-1}$ (measured from OW in 2016). Our results are of the same magnitude as ebullition fluxes previously measured in boreal peatlands with gas traps, ranging from 7 to $96 \mathrm{mg} \mathrm{m}^{-2} \mathrm{~d}^{-1}$ (Strack et al., 2005; Strack and Waddington, 2008; Stamp et al., 2013), and with automatic chambers, ranging from 9 to $152 \mathrm{mg} \mathrm{m}^{-2} \mathrm{~d}^{-1}$ (Goodrich et al., 2011). In addition to field measurements, some of the laboratory-based experiments have shown similar ebullition flux rates in the range of $0-270 \mathrm{mg} \mathrm{m}^{-2} \mathrm{~d}^{-1}$ (Christensen et al., 2003; Kellner et al., 2006; Yu et al., 2014) but also higher fluxes up to $784 \mathrm{mg} \mathrm{m}^{-2} \mathrm{~d}^{-1}$ (Green and Baird, 2012). Some laboratory studies have even shown potential for much higher ebullition rates up to $33000 \mathrm{mg} \mathrm{m}^{-2} \mathrm{~d}^{-1}$ (Sphagnum surface samples from bog in Tokida et al., 2005; fen lawn samples in Waddington et al., 2009). So far, only Tokida et al. (2007) have estimated ebullition fluxes reaching $1440 \mathrm{mg} \mathrm{m}^{-2} \mathrm{~d}^{-1}$ in the field based on methane fluxes measured with the static chamber method from two sample plots showing high episodic fluxes during $30 \mathrm{~min}$ measurements. Generally, there is a difference in temporal resolution between the two methods as chamber measurements usually cover only short time periods (from minutes to hours), while gas traps show estimates of cumulative bubble flux over several days.

The fact that the ebullition rates measured with gas traps are lower than in laboratory studies might be partly explained by the process of bubbles stacking in the gas traps instead of automatically gathering in the headspace. In this study, we tried to overcome this potential error source by gently shaking and tapping the gas traps before sampling, simultaneously trying to avoid causing more ebullition from this disturbance. However, methane ebullition fluxes of up to $1683 \mathrm{mg} \mathrm{m}^{-2} \mathrm{~d}^{-1}$ have been previously measured with the same method from subarctic lakes (Wik et al., 2013), which shows the potential of this method to also measure higher ebullition fluxes.

\subsection{Temporal and spatial variation}

Our study conducted over three growing seasons showed inter-annual variation. The highest ebullition on average was measured in 2016, whereas the average flux rates of 2014 and 2015 did not differ significantly from each other. More ebullition was measured from BP in 2016 especially, which was the wettest year with the highest WT. This indicates that despite higher WT increasing hydrostatic pressure in 

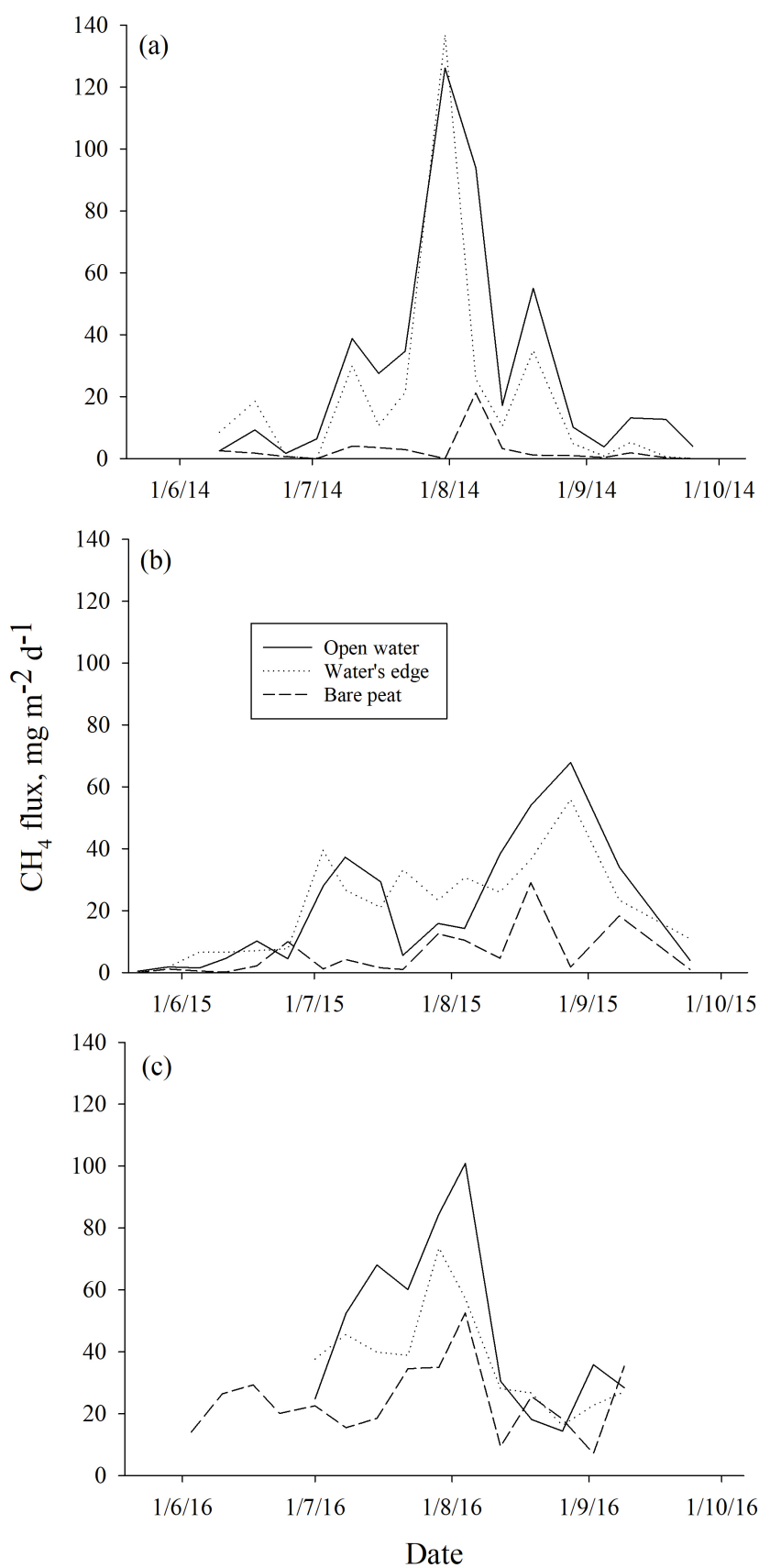

Figure 3. Mean methane ebullition measured weekly in Siikaneva bog over three consecutive years (a) 2014, (b) 2015 and (c) 2016 over different surfaces: bare peat, open water and the water's edge.

peat, wetter conditions in BP facilitate gas release as bubbles. Although 2015 was almost as wet a year as 2016, it was much cooler, which decreases methane production. The warmest year (2014) again was much drier than 2016, and although there was high ebullition with sharp drop in WT during the peak season, the general ebullition level from BP was low. The only other peatland study with gas traps covering more than one growing season (Strack and Waddington,
2008) also found the ebullition level to differ between the study years. Similarly, Wik et al. (2013) found differences in bubble methane concentrations and fluxes in subarctic lakes among the four summers studied. These results point out the need for multi-year studies in order to include inter-annual variation in ebullition fluxes in methane models. Furthermore, the higher ebullition rate from $\mathrm{W}$ than from $\mathrm{BP}$ in our study indicates that balanced sampling in a bog should cover microform variability, although in some studies no spatial variation in ebullition were found (Green and Baird, 2012, 2013; Stamp et al., 2013). However, drier and wetter conditions can change the proportions of water and bare peat surfaces, and, according to our results, such changes may have an impact on ebullition.

\subsection{Controlling factors and their importance}

The measured ebullition rates increased together with peat temperature as also shown earlier (Strack and Waddington, 2008). Increasing temperature generally increases the activity of methanogens, and thus more methane is produced in the peat when it gets warmer, until the temperature optimum of the microbes around $20-30^{\circ} \mathrm{C}$ is reached (Dunfield et al., 1993). Peat temperature affects also the solubility of methane, according to Henry's law, as gas solubility decreases with increasing temperature (Strack et al., 2005). Thus, increasing peat temperature may lead to transfer of methane from aqueous to gaseous phase, which increases bubble formation (Strack et al., 2005). In our study, the peat temperature at the depth of $5 \mathrm{~cm}$ showed the highest correlation with ebullition but temperature at all depths was highly intercorrelated. The effect of peat temperature was reflected in the seasonal pattern of ebullition.

As expected, ebullition fluxes increased when WT decreased, as found in previous studies (Strack and Waddington, 2008). Bubbles may accumulate in peat under barriers, such as pieces of wood, and they are suppressed by high hydrostatic or air pressure (Rosenberry et al., 2003; Strack and Waddington, 2008; Chen and Slater, 2015). Decreasing WT lowers the hydrostatic pressure, releasing newly formed and the accumulated bubbles. Many studies have also shown that the falling atmospheric pressure can trigger high rates of ebullition (Tokida et al., 2005, 2007). Although some weeks showed higher ebullition rates when atmospheric pressure was falling, this pattern was not consistent as increasing ebullition rates were also measured during periods of rising atmospheric pressure. After including WT as explanatory variable, we still found the weekly change in atmospheric pressure to significantly affect ebullition, as bigger increase in weekly pressure was related to more ebullition. Previously, Comas et al. (2011) used ground penetrating radar (GPR) to study the vertical distribution of free-phase gas in a northern peatland and found that increasing atmospheric pressure caused rapid ebullition by releasing gas from shallow peat, whereas decreasing pressure released gas from deeper peat 

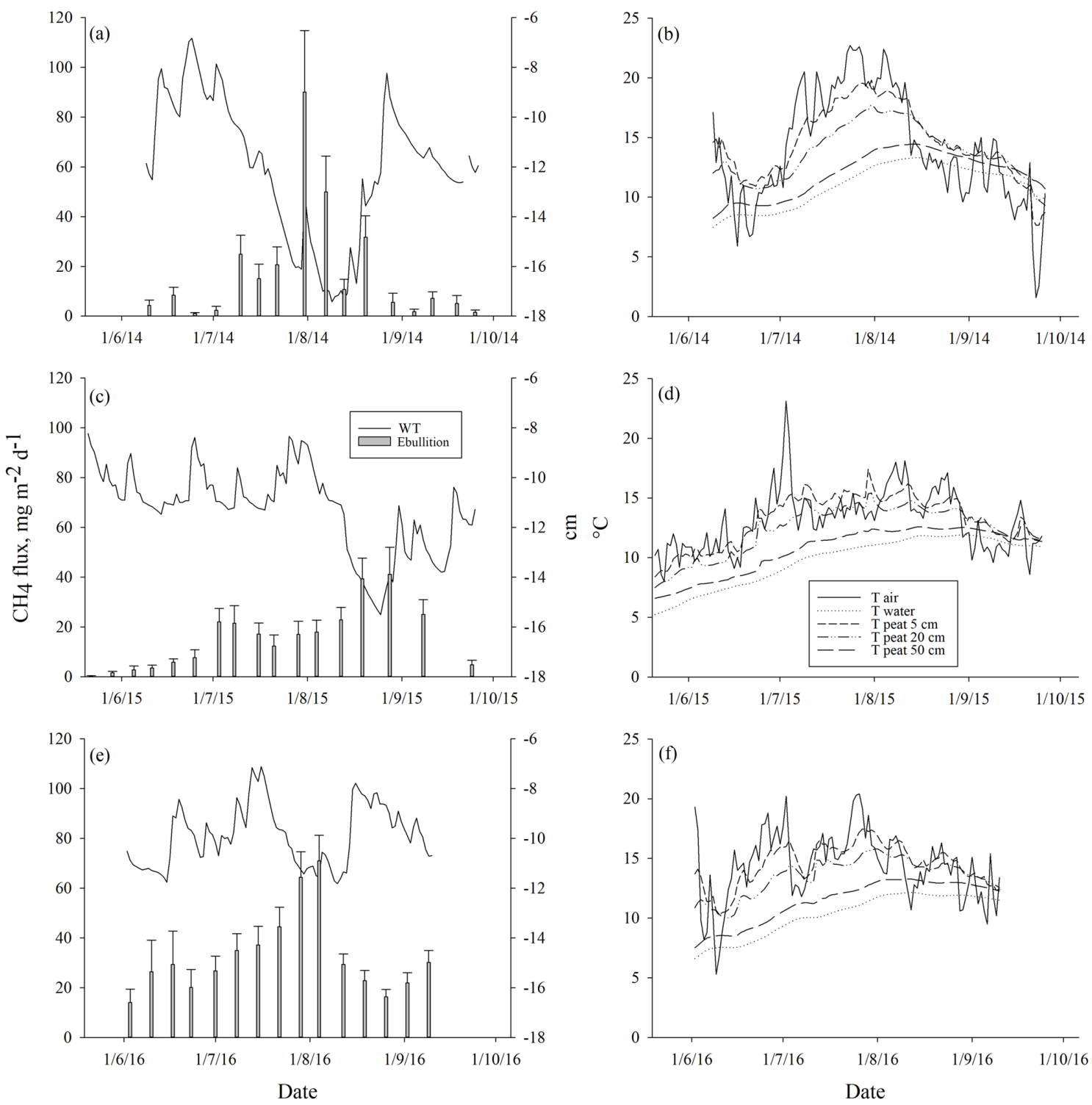

Figure 4. Mean weekly methane ebullition with standard error of the means from all surfaces compared to water table (WT) (a, c, e), and air, water, and peat temperatures at the depths of 5, 25 and $50 \mathrm{~cm}(\mathbf{b}, \mathbf{d}, \mathbf{f})$ measured in Siikaneva bog in the years (a-b) $2014,(\mathbf{c}-\mathbf{d}) 2015$ and (e-f) 2016 .

to shallow layers. Also, Chen and Slater (2015) showed that increasing pressure can trigger ebullition as it increases the bubble mobility in peat.

Furthermore, higher ebullition rates were measured with a higher effective temperature sum of the measurement period. This indicates the importance of energy input as a driver of methane production and release as shown by Wik et al. (2014). They found strong positive correlations between seasonal bubble methane flux from subarctic lakes and four proxies of energy flux, such as average short-wave radiation and maximum water sediment temperature (Wik et al., 2014). We tried also to compare cumulative PAR (i.e. short-wave radiation) to seasonal cumulative ebullition fluxes but could not find clear correlation between the two in the three study years. However, the positive effect of the measurement period temperature sum on ebullition shows that increasing energy input can increase ebullitive methane flux rates at the studied bog site.

\subsection{Importance for the ecosystem-level flux}

When measured ebullition fluxes were upscaled to the ecosystem level, they showed much lower methane emissions than measured with chamber and EC techniques. In our previous study (Korrensalo et al., 2018b), we measured diffusive methane fluxes with the static chamber technique from six different plant community types, including BP, at 

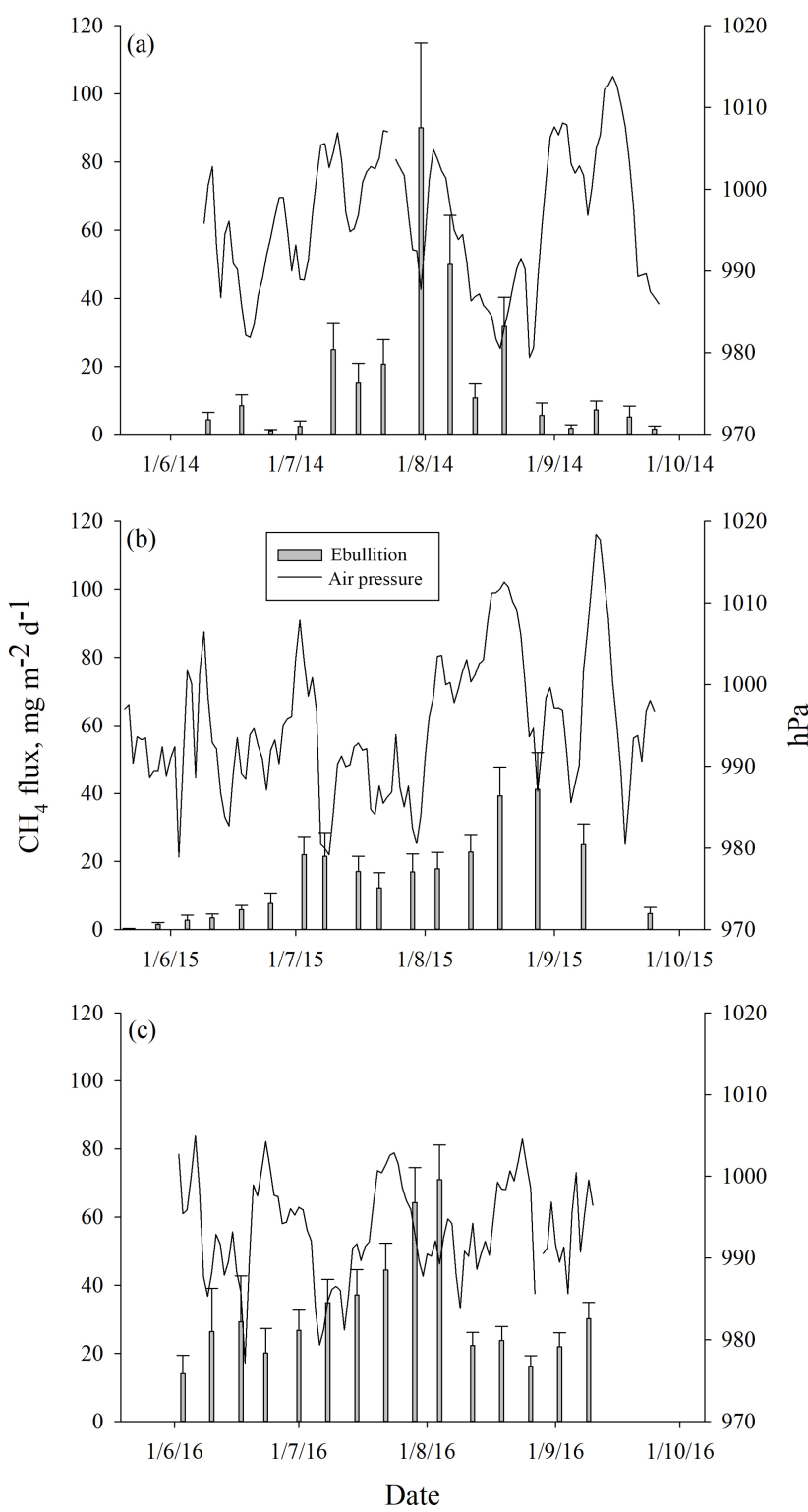

Figure 5. Mean weekly methane ebullition from all surfaces compared to atmospheric pressure measured in Siikaneva bog in (a) 2014, (b) 2015 and (c) 2016.

the same bog site in 2014. We found higher methane fluxes from BP than from high hummocks (HHU), but otherwise all the studied plant community types had similar methane fluxes. When chamber fluxes were upscaled to ecosystem level, they were similar to the EC flux (Korrensalo et al., 2018b). Although laboratory incubation studies have shown that the contribution of ebullition to the total methane flux may reach up to $50 \%$ (Christensen et al., 2013; Tokida et al., 2007 ), the ebullition contribution in this study was only $3 \%-$ $5 \%$ during the peak season of 2014. Here, ebullition is only considered from waterlogged surfaces, as we did not measure ebullition from vegetated surfaces. Previously, Riutta
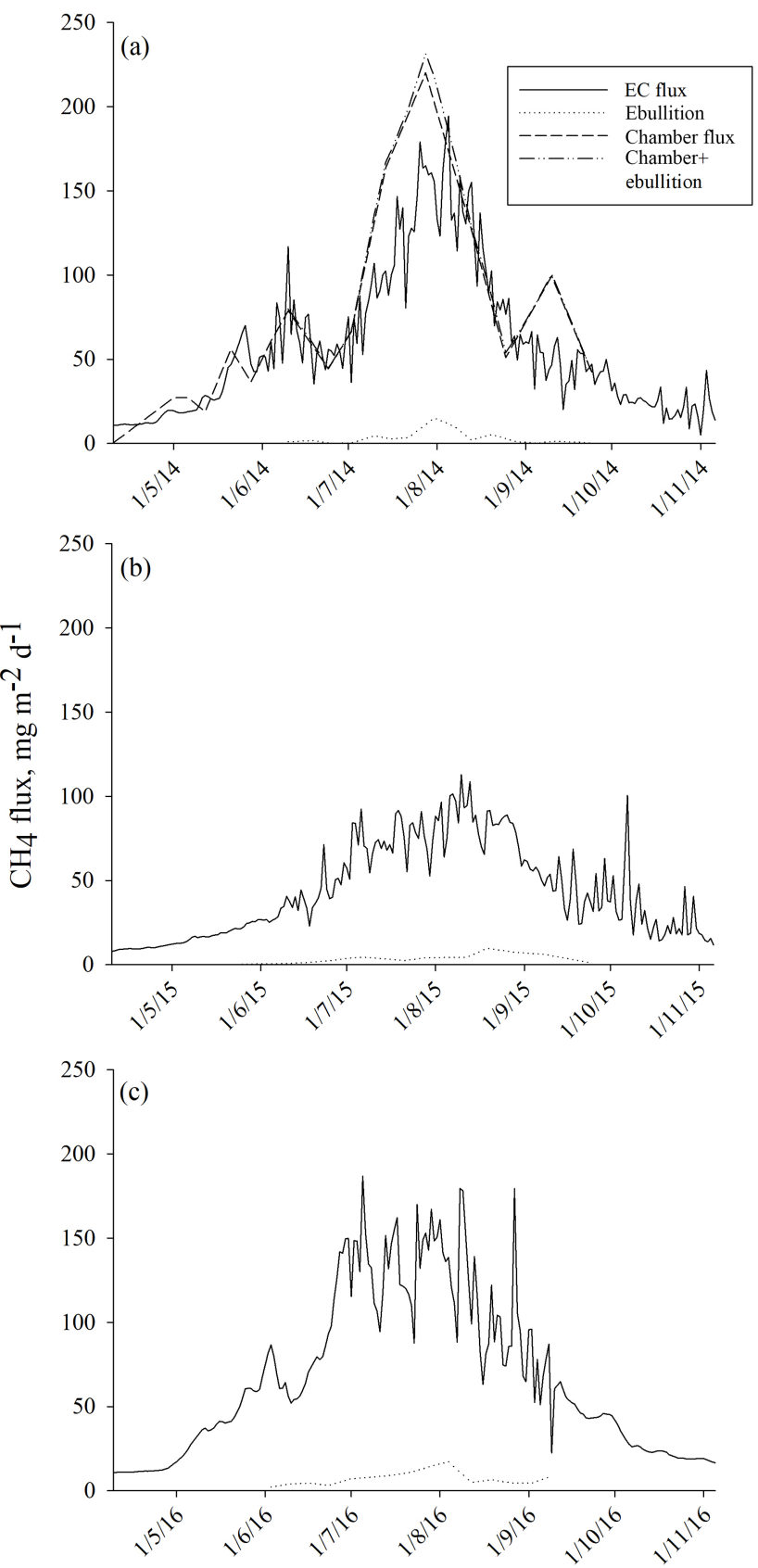

Date

Figure 6. Ecosystem-level methane fluxes measured with the eddy covariance (EC) technique and upscaled from ebullition measurements in (a) 2014, (b) 2015 and (c) 2016. In 2014, ecosystem-level methane fluxes are also compared to upscaled chamber fluxes.

et al. (2007) measured methane fluxes from different plant communities with static chambers at the Siikaneva fen site, situated $1.3 \mathrm{~km}$ south-east of our studied bog site, and calculated results for both diffusive and ebullition fluxes. They found ebullition from all communities but showed that its contribution to the total flux (diffusive flux plus ebullition) was negligible or very small (Riutta et al., 2007). We esti- 
mated ebullition to occur only twice in 210 measurements on moss-covered surfaces, i.e. in $0.8 \%$ of our 2014 chamber data. Therefore, we assume that ebullition from vegetated surfaces would not greatly contribute to the total flux at the bog site either. Earlier, similar to our study, Green and Baird (2013) found ebullition to contribute less than $3.3 \%$ of total methane fluxes when incubating peat samples collected from hollows and lawns from two raised bogs in laboratory study. As the measured bubble methane fluxes in our study were of the same magnitude in each year, ebullition did not contribute significantly to the ecosystem methane emissions in any studied growing season, as seen in the comparison with the EC flux. While the same seasonal trend and peaks can be seen in both fluxes in each year, the total flux measured with EC is constantly at least an order of magnitude higher than the ebullition flux rate.

\section{Conclusions}

More methane ebullition was found from $\mathrm{W}$ than from BP, and within the pools more bubbles were released from $\mathrm{OW}$ than from EW. We also found variation between the three studied growing seasons, as ebullition rate was generally higher in the wettest year (2016). Due to this spatial and temporal variation, differences between years in wet or dry conditions may have an effect on ebullition. As expected, ebullition increased together with increasing peat temperature, which facilitates methane production, and with decreasing WT, which reduces hydrostatic pressure on peat. Additionally, more bubbles were released with a bigger weekly increase in atmospheric pressure, which is related to rapid ebullition from shallow peat. Furthermore, a higher weekly temperature sum had a positive effect on ebullition, which shows that increasing energy input can increase ebullitive methane flux rates at the studied bog site. Therefore, the growing season lengthening and the increase in the average temperatures due to climate change may increase the methane emissions in the peatland ecosystem, as long as waterlogged anoxic conditions in the peat for methane production persist. Ebullition flux upscaled to the ecosystem level showed a similar seasonal pattern to methane fluxes measured with EC and chamber techniques but was an order of magnitude lower and had a very small contribution to the total ecosystem flux. Our study only includes ebullition from the waterlogged surfaces, as we did not expect ebullition from all the plant community types to be substantial based on the previous study at the nearby fen site and our chamber measurements in 2014. However, estimating the amount of ebullition from all the plant community types would be needed to fully understand the spatial variation in ebullition in the future. In addition, measurements with, e.g. time-lapse cameras, are needed to study the short-term temporal variation in ebullition and to estimate the frequency and magnitude of rapid ebullition events that may contribute to the total ecosystem flux.
Data availability. The data used in this study are available upon request from the corresponding author. 


\section{Appendix A}

Table A1. Mean methane concentrations of the gas caught in the gas traps and of fresh ebullition samples in 2014. Concentration samples were collected four times from gas traps on water (W) and bare peat (BP) surfaces and by triggering fresh ebullition from similar surfaces.

\begin{tabular}{lrrrr}
\hline \multirow{2}{*}{ Date } & \multicolumn{4}{c}{ Mean $\mathrm{CH}_{4}$ concentration $\mathrm{mLL}^{-1}$} \\
\cline { 2 - 5 } & W gas trap & BP gas trap & W fresh & BP fresh \\
\hline 10 Jun & 17 & 45 & 293 & 268 \\
16 Jul & 61 & 245 & 420 & 313 \\
13 Aug & 86 & 152 & 399 & 172 \\
5 Sep & 49 & 63 & 379 & 221 \\
\hline
\end{tabular}

Numbers in italics indicate the concentration in a single measured gas trap, as opposed to a mean of many gas traps.
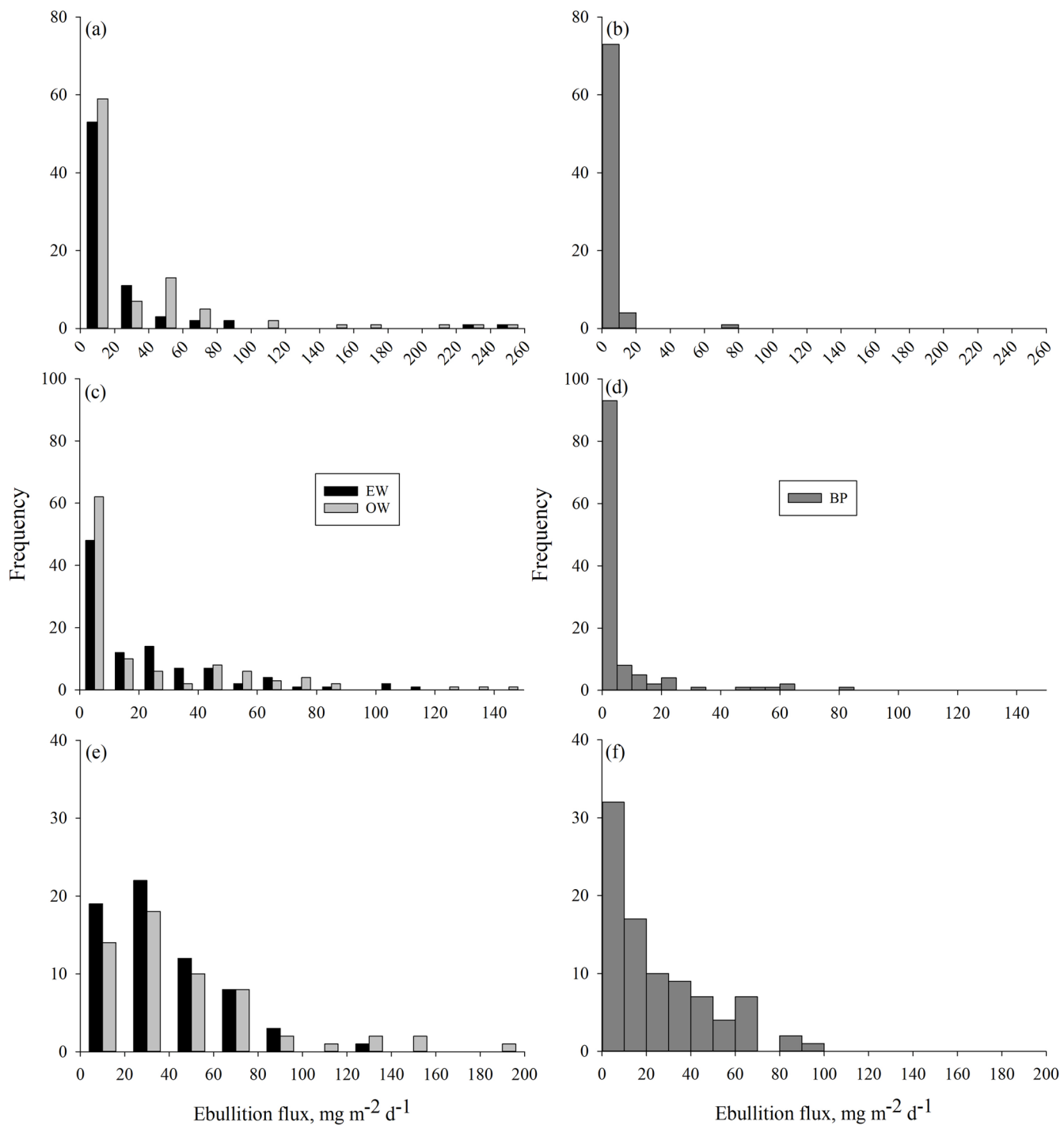

Figure A1. Frequency distribution of methane ebullition $\left(\mathrm{mg} \mathrm{m}^{-2} \mathrm{~d}^{-1}\right)$ per gas trap from open water pools (OW), the water's edge (EW) and bare peat surfaces (BP) in (a-b) 2014, (c-d) 2015 and (e-f) 2016. Note the differences in scales between the years. 
Author contributions. AK, EST, PA and TV came up with the idea and design. AK and EM conducted the ebullition measurements and processed the data. Eddy covariance data was collected and analysed by PA and IM. EM fitted the mixed-effect models. The manuscript was written by EM, AK and EST and commented on by all the other authors.

Competing interests. The authors declare that they have no conflict of interest.

Acknowledgements. We thank Hyytiälä Forest Research Station and its staff for research facilities and Pauli Karppinen from Natural Resources Institute Finland (LUKE) for analysing methane concentration of the fresh bubble samples. We also thank Salli Uljas, Janne Sormunen, Franziska Rossocha and Laura Kettunen for the help in the field.

Financial support. This research has been supported by the Academy of Finland (grant no. 287039), the Finnish Cultural Foundation (grant no. 00170743), the Academy research project CLIMOSS (grant no. 41007-00086900), the Strategic Research Council research project SOMPA (grant no. 41007-00114600), the National Centre of Excellence (grant no. 272041), the ICOSFinland (grant no. 281255), the Academy professor project funded by the Academy of Finland, AtMath funded by the University of Helsinki (grant no. 284701), and the Postdoctoral Researcher project funded by the Academy of Finland (grant no. 315424).

Review statement. This paper was edited by Alexey V. Eliseev and reviewed by two anonymous referees.

\section{References}

Ahti, T., Hämet-Ahti, L., and Jalas, J.: Vegetation zones and their sections in northwestern Europe, Ann. Bot. Fenn., 5, 169-211, 1968.

Bosse, U. and Frenzel, P.: Activity and Distribution of MethaneOxidizing Bacteria in Flooded Rice Soil Microcosms and in Rice Plants (Oryza sativa), Appl. Environ. Microb., 63, 1199-1207, 1997.

Brown, M. G., Humphreys, E. R., Moore, T. R., Roulet, N. T., and Lafleur, P. M.: Evidencefor a nonmonotonic relationship between ecosystem-scale peatland methane emissions and water table depth, J. Geophys. Res.-Biogeo., 119, 826-835, https://doi.org/10.1002/2013JG002576, 2014.

Bubier, J., Moore, T., Savage, K., and Crill, P.: A comparison of methane flux in a boreal landscape between a dry and a wet year, Global Biogeochem. Cy., 19, GB1023, https://doi.org/10.1029/2004GB002351, 2005.

Chen, X. and Slater, L.: Gas bubble transport and emissions for shallow peat from a northern peatland: The role of pressure changes and peat structure, Water Resour Res., 51, 151-168, https://doi.org/10.1002/2014WR016268, 2015.
Christensen, T. R., Panikov, N., Mastepanov, M., Joabsson, A., Stewart, A., Öquist, M., Sommerkorn, M., Reynald, S., and Svensson, B.: Biotic controls on $\mathrm{CO}_{2}$ and $\mathrm{CH}_{4}$ exchange in wetlands - a closed environment study, Biogeochemistry, 64, 337254, 2003.

Comas, X., Slater, L., and Reeve, A. S.: Atmospheric pressure drives changes in the vertical distribution of biogenic free-phase gas in a northern peaetland, J. Geophys. Res., 116, G04014, https://doi.org/10.1029/2011JG001701, 2011.

Conrad, R., Schultz, H., and Babbel, M.: Temperature imitation of hydrogen turnover and methanogesis in anoxic paddy soil, FEMS Microbiol. Ecol., 45, 281-289, 1997.

Dunfield, P., Knowles, R., Dumont, R., and Moore, T. R.: Methane production and consumption in temperate and subarctic peat soils: Response to temperature and $\mathrm{pH}$, Soil Biol. Biochem., 25, 321-326, 1993.

Finnish Meteorological Institute open data: available at: https://en. ilmatieteenlaitos.fi/open-data, last access: 8 May 2019.

Frenzel, P. and Rudolph, J.: Methane emission from a wetland plant: the role of $\mathrm{CH}_{4}$ oxidation in Eriophorum, Plant Soil, 202, 27-32, 1998.

Goodrich, J. P., Varner, R. K., Frolking, S., Duncan, S. B., and Crill, P. M.: High-frequency measurements of methane ebullition over a growing season at a temperate peatland site, Geophys. Res. Lett., 38, L07404, https://doi.org/10.1029/2011GL046915, 2011.

Green, S. M. and Baird, A. J.: A Mesocosm study of the role of the sedge Eriophorun angustifolium in the efflux of methane including that due to episodic ebullition - from peatlands, Plant Soil, 351, 207-218, 2012.

Green, S. M. and Baird, A. J.: The importance of episodic ebullition methane losses from three peatland microhabitats: a controlledenvironment study, Eur. J. Soil. Sci., 64, 27-36, 2013.

Hamilton, J. D., Kelly, C. A., Rudd, J. W. M., Hesslein, R. H., and Roulet, N. T.: Flux to the atmosphereof $\mathrm{CH}_{4}$ and $\mathrm{CO}_{2}$ from wetland ponds on the Hudson Bay lowlands (HBLs), J. Geophys. Res., 99, 1495-1519, 1994.

Hanson, R. S. and Hanson, T. E.: Methanotrophic Bacteria, Microbiol. Rev., 60, 439-471, 1996.

IPCC: Climate Change 2014: Synthesis Report, Contribution of Working Groups I, and III to the Fifth Assessment Report of the Intergovernmental Panel on Climate Change, edited by: Core Writing Team, Pachauri, R. K. and Meyer, L. A., IPCC, Geneva, Switzerland, 151 pp., 2014.

Jackowicz-Korczyński, M., Christensen, T. R., Bäckstrand, K., Crill, P., Friborg, T., Mastepanov, M., and Ström, L.: Annual cycle of methane emission from a subarctic peatland, J. Geophys. Res., 115, G02009, https://doi.org/10.1029/2008JG000913, 2010.

Kellner, E., Baird, A. J., Oosterwoud, M., Harrison, K., and Waddington, J. M.: Effect of temperature and atmospheric pressuer on methane $\left(\mathrm{CH}_{4}\right)$ ebullition from near-surface peats, Geophys. Res. Lett., 33, L18405, https://doi.org/10.1029/2006GL027509, 2006.

Korrensalo, A., Kettunen, L., Laiho, R., Alekseychik, P., Vesala, T., Mammarella, I., and Tuittila, E.-S.: Boreal bog plant communities along a water-table gradient differ by their standing biomass but not by their biomass production, J. Veg. Sci., 29, 136-146, https://doi.org/10.1111/jvs.12602, 2018a. 
Korrensalo, A., Männistö, E., Alekseychik, P., Mammarella, I., Rinne, J., Vesala, T., and Tuittila, E.-S.: Small spatial variability in methane emission measured from a wet patterned boreal bog, Biogeosciences, 15, 1749-1761, https://doi.org/10.5194/bg-151749-2018, 2018b.

Larmola, T., Tuittla, E.-S., Tiirola, M., Nykänen, H., Martikainen, P. J., Yrjälä, K., Tuomivirta, T., and Fritze, H.: The role of Sphanum mosses in the methane cycling of a boreal mire, Ecology, 91, 2356-2365, 2010.

LeMer, J. and Roger, P.: Production, oxidation, emission and consumption of methane by soils: A review, Eur. J. Soil Biol., 37, 25-50, 2001.

Melton, J. R., Wania, R., Hodson, E. L., Poulter, B., Ringeval, B., Spahni, R., Bohn, T., Avis, C. A., Beerling, D. J., Chen, G., Eliseev, A. V., Denisov, S. N., Hopcroft, P. O., Lettenmaier, D. P., Riley, W. J., Singarayer, J. S., Subin, Z. M., Tian, H., Zürcher, S., Brovkin, V., van Bodegom, P. M., Kleinen, T., Yu, Z. C., and Kaplan, J. O.: Present state of global wetland extent and wetland methane modelling: conclusions from a model intercomparison project (WETCHIMP), Biogeosciences, 10, 753788, https://doi.org/10.5194/bg-10-753-2013, 2013.

Meredith, M.: Hazards in the bog-real and imagined, Geogr. Rev., 92, 319-332, 2002.

Mikhaylov, O. A., Miglovets, M. N., and Zagirova, S. V.: Vertical Methane Fluxes in Mesooligotrophic Boreal Peatland in European Northeast Russia, Contemp. Probl. Ecol., 8, 368-375, 2015.

Peltola, O., Raivonen, M., Li, X., and Vesala, T.: Technical note: Comparison of methane ebullition modelling approaches used in terrestrial wetland models, Biogeosciences, 15, 937-951, https://doi.org/10.5194/bg-15-937-2018, 2018.

Petrescu, A. M. R., Lohila, A., Tuovinen, J.-P., Baldocchi, D. D., Desai, A. R., Roulet, N. T., Vesala, T., Dolman, A. J., Oechel, W. C., Marcolla, B., Friborg, T., Rinne, J., Matthes, J. H., Merbold, L., Meijide, A., Kiely, G., Sottocornola, M., Sachs, T., Zona, D., Varlagin, A., Lai, D. Y. F., Veenendaal, E., Parmentier, F.-J. W., Skiba, U., Lund, M., Hensen, A., van Huissteden, J., Flanagan, L. B., Shurpali, N. J., Grünwald, T., Humphreys, E. R., JackowiczKorczyński, M., Aurela, M. A., Laurila, T., Grüning, C., Corradi, C. A. R., Schrier-Uijl, A. P., Christensen, T. R., Tamstorf, M. P., Mastepanov, M., Martikainen, P. J., Verma, S. B., Bernhofer, C., and Cescatti, A.: The uncertain climate footprint of wetlands under human pressure, P. Natl. Acad. Sci. USA, 112, 4594-4599, 2015

Raghoebarsing, A. A., Smolders, A. J., Schmid, M. C., Rijpstra, W. I. C., Wolters-Arts, M., Derksen, J., Jetten, M. S., Schouten, S., Sinninghe Damsté, J. S., Lamers, L. P., Roelofs, J. G., Op den Camp, H. J., and Strous, M.: Methanotrophic symbionts provide carbon for photosynthesis in peat bogs, Nature, 436, 1153-1156, 2005.

Ramirez, J. A., Baird, A. J., and Coulthard, T. J.: The effect of pore structure on ebullition from peat, J. Geophys. Res.-Biogeo., 121, 1646-1656, https://doi.org/10.1002/2015JG003289, 2016.

Riley, W. J., Subin, Z. M., Lawrence, D. M., Swenson, S. C., Torn, M. S., Meng, L., Mahowald, N. M., and Hess, P.: Barriers to predicting changes in global terrestrial methane fluxes: analyses using CLM4Me, a methane biogeochemistry model integrated in CESM, Biogeosciences, 8, 1925-1953, https://doi.org/10.5194/bg-8-1925-2011, 2011.
Rinne, J., Riutta, T., Pihlatie, M., Aurela, M., Haapanala, S., Tuovinen, J.-P., Tuittila, E.-S., and Vesala, T.: Annual cycle of methane emission from a boreal fen measured by the eddy covariance technique, Tellus B, 59, 449-457, 2007.

Rinne, J., Tuittila, E.-S., Peltola, O., Li, X., Raivonen, M., Alekseychik, P., Haapanala, S., Pihlatie, M., Aurela, M., Mammarella, I., and Vesala, T.: Temporal variation of ecosystem scale methane emission from a boreal fen in relation to temperature, water table position, and carbon dioxide fluxes, Global Biogeochem. Cy., 32, 1087-1106, 2018.

Riutta, T., Laine, J., Aurela, M., Rinne, J., Vesala, T., Laurila, T., Haapanala, S., Pihlatie, M., and Tuittila, E.-S.: Spatial variation in plant community functions regulates carbon gas dynamics in a boreal fen ecosystem, Tellus B, 59, 838-852, 2007.

Rosenberry, R. O., Glaser, O. H., Siegel, D. I., and Weeks, E. P.: use of hydraulic head to estimate volumetric gas content and ebullition flux in northern peatlands, Water Resour Res., 39, 1066, https://doi.org/10.1029/2002WR001377, 2003.

Stamp, I., Baird, A. J., and Heppell, C. M.: The importance of ebullition as a mechanism of methane $\left(\mathrm{CH}_{4}\right)$ loss to the atmosphere in a northern peatland, Geophys. Res. Lett., 40, 2087-2090, 2013.

Strack, M.: Peatlands and climate change, Jyväskylä, Finland, International Peat Society, 2008.

Strack, M. and Waddington, J. M.: Spatiotemporal variability in peatland subsurface methane dynamics, J. Geophys. Res., 113, G02010, https://doi.org/10.1029/2007JG000472, 2008.

Strack, M., Kellner, E., and Waddington, J. M.: Dynamics of biogenic gas bubbled in peat and their effects on peatland biogeochemistry, Global Biogeochem. Cy., 19, GB1003, https://doi.org/10.1029/2004GB002330, 2005.

Ström, L., Mastepanov, M., and Christensen, T. R.: Species-specific effects of vascular plants on carbon turnover and methane emissions from wetlands, Biogeochemistry, 75, 65-82, 2005.

Tokida, T., Miyazaki, T., and Mizoguchi, M.: Ebullition of methane from peat with falling atmospheric pressure, Geophys. Res. Lett., 32, L13823, https://doi.org/10.1029/2005GL022949, 2005.

Tokida, T., Miyazaki, T., Mizoguchi, M., Nagata, O., Takakai, F., Kagemoto, A., and Hatano, R.: Falling atmospheric pressure as a trigger for methane ebullition from peatland, Global Biogeochem. Cy., 21, GB2003, https://doi.org/10.1029/2006GB002790, 2007.

Turetsky, M. R., Kotowska, A., Bubier, J., Dise, N. B., Crill, P., Hornibrook, E. R. C., Minkkinen, K., Moore, T. R., Myers-Smith, I. H., Nykänen, H., Olefeldt, D., Rinne, J., Saarnio, S., Shurpali, N., Tuittila, E.-S., Waddington, J. M., White, J. R., Wickland, K. P., and Wilmking, M.: A synthesis of methane emissions from 71 northern, temperate, and subtropical wetlands, Glob. Change Biol., 20, 2183-2197, https://doi.org/10.1111/gcb.12580, 2014.

Waddington, J. M., Harrison, K., Kellner, E., and Baird, A. J.: Effect of atmospheric pressure and temperature on entrapped gas content in peat, Hydrol. Process., 23, 2970-2980, 2009.

Wik, M., Crill, P. M., Varner, R. K., and Bastviken, D.: Multiyear measurements of ebullitive methane flux from three subarctic lakes, J. Geophys. Res.-Biogeo., 118, 1307-1321, 2013.

Wik, M., Thorton. B. F., Bastviken, D., MacIntyre, S., Verner, R. K., and Crill, P. M.: Energy input is primary controller of methane bubbling in subarctic lakes, Geophys. Res. Lett., 41, 555-560, https://doi.org/10.1002/2013GL058510, 2014. 
Yu, Z., Slater, L. D., Schäfer, K. V. R., Reeve, A. S., and Verner, R. K.: Dynamics of methane ebullition from a peat monolith revealed from a dynamic flux chamber system, J. Geophys. Res.-Biogeo., 119, 1789-1806, https://doi.org/10.1002/2014JG002654, 2014. 